\title{
Negociações simbólicas das regras religiosas do vestir em postagens no Instagram
}

Symbolic negotiations of the religious rules of dressing in posts on Instagram 
Raphael Daróz de Almeida ${ }^{1}$

ORCID: https://orcid.org/0000-0003-1576-1585

Leticia Moreira Casotti ${ }^{2}$

ORCID: https://orcid.org/0000-0001-7718-5072

\section{Ana Paula Celso de Miranda ${ }^{3}$}

ORCID: https://orcid.org/0000-0002-0605-4144

[resumo] 0 objetivo deste estudo de abordagem interpretativa foi analisar postagens, em redes sociais, de grupos religiosos femininos em busca de negociações simbólicas que, a partir da moda, profanam o sagrado e sacralizam o profano. 0 percurso metodológico ancorou-se na captação e na análise das imagens de looks construídos, das legendas que as acompanham e dos textos e comentários compartilhados juntamente com as fotos. Dez contas de Instagram de mulheres caracterizadas como influenciadoras digitais e identificáveis como pertencentes à igreja Assembleia de Deus - foram acompanhadas e analisadas. Os resultados encontrados discutem sobre o uso, por essas mulheres, do capital da moda para borrar os limites das regras religiosas, fazendo negociações simbólicas entre o campo mundano e o religioso, o que nos permitiu relacionar esses achados com a sociedade da transparência de Han.

\section{[palavras-chave] Moda. Consumo. Cultura. Religião. Influência digital.}

[abstract] The objective of this study of an interpretative approach was to analyze posts by female religious groups on social networks in search of symbolic negotiations that profane the sacred and sanctify the profane. The methodological path was anchored in the capture and analysis fashion looks, the captions that accompany the images and the texts and comments also shared along with the images. 10 Instagram accounts of women characterized as digital influencers and who could be identified as belonging to the Assembly of God Church were monitored and analyzed. The results found discuss the use of fashion capital by these women to blur the limits of religious rules by making symbolic negotiations between the mundane and the religious fields, which allowed us to relate these findings to the Han Transparency Society.

[keywords] Fashion. Consumption. Culture. Religion. Digital influence.

Recebido em: 30-07-2020

Aprovado em: 05-12-2020

\footnotetext{
${ }^{1}$ Mestrando no Instituto Coppead de Administração (UFRJ). Mestre em Letras pela FFLCH (USP). E-mail: prraphael@hotmail.com. Lattes: http://Lattes.cnpq.br/0013671956244608.

2 Doutora em Engenharia de Produção pela Coppe (UFRJ). Professora associada do Instituto Coppead de Administração (UFRJ). E-mail: leticia@coppead.ufrj.br. Lattes: http://lattes.cnpq.br/0464268640054997.

3 Pós-doutorado no Instituto Coppead de Administração (UFRJ). Professora associada do Núcleo de Design e Comunicação da UFPE. E-mail: anapaula.miranda@ufpe.br. Lattes: http://lattes.cnpq.br/5061912856624094.
} 


\section{Introdução}

Religiões têm servido como uma estrutura de socialização de seus seguidores e costumam definir questões morais que se ligam, por exemplo, às relações familiares. Historicamente, a religião exerce um papel estruturante nas diversas sociedades (BOURDIEU, 1991). Diferentes doutrinas interferem em comportamentos de consumo secular (MULINA, 2019) e pesquisadores associam o consumo à religião dentro da perspectiva cultural; nesse sentido, alguns estudos recentes sugerem uma diluição do papel da religião como influenciadora do comportamento do consumidor (SOBH; BELK; GRESSEL, 2012, 2014; MCALEXANDER; DUFAULT; MARTIN; SCHOUTEN, 2014; RENTAS VEGA, 2019; SANDIKC; GER, 2010). Entre as categorias de produtos de consumo, tem-se o vestuário como uma das que sofre essa influência (CESAR, 2010).

Neste estudo, entendemos o vestuário como o conjunto das roupas que compõem o traje, os complementos e acessórios que o acompanham e que formam a estética. 0 look possui uma composição mais abrangente; além de roupas e acessórios, também se refere à maquiagem, penteados e atitudes que, misturados, idealizam determinada aparência, ou seja, no look, tais elementos se comportam como adjuvantes do texto visual (GARCIA; MIRANDA, 2005).

O sistema da moda é um dos instrumentos que possibilita negociações simbólicas mediadas pela cultura. Posto que as crenças religiosas estão entre os principais fatores que moldam comportamentos e, portanto, dão origem a negociações simbólicas (MCCRACKEN, 2003), considerando-se o campo religioso uma importante manifestação da cultura - capaz de construir categorias, princípios e um sistema de significados, atitudes e valores -, a moda se apresenta como um regime capaz de movimentar significados dentro do campo religioso por meio dos líderes de opinião que, no contexto do nosso estudo, são as influenciadoras digitais.

Este estudo buscou compreender como grupos femininos religiosos usam as redes sociais como uma plataforma de negociações simbólicas entre o sagrado (regras declaradas) e o secular (o fluxo da moda). Com esse objetivo, foram selecionadas imagens de contas do Instagram para análise dos looks de digital influencers, encontradas a partir de um mapeamento de hashtags associadas à Igreja Evangélica Assembleia de Deus no Brasil (IEADB). A IEADB é reconhecida como a maior denominação evangélica e a segunda instituição religiosa no país quanto ao número de fiéis, atrás apenas da Igreja Católica. A IEADB representava, já em 2010, um grupo de mais de 12,3 milhões de pessoas (IBGE, 2010).

0 pentecostalismo despontou no Brasil no início do século XX como um movimento profundamente ascético e sectário (FERREIRA, 2015), o que contribuiu para que seus fiéis desenvolvessem uma maneira peculiar de se vestir. Sabe-se que a IEADB impõe a seus fiéis normas capazes de afetar seus hábitos de consumo (ALBUQUERQUE; DUQUE-ARRAZOLA; ROCHA, 2018; ALVES, 2009, 2012). Algumas delas dizem respeito especificamente ao consumo de moda e beleza e são dirigidas especialmente às mulheres, que se definem como assembleianas ou simplesmente bleianas. 
O campo dos estudos em consumo vem contribuindo para compreender a formação de mercado e o comportamento de consumo associado à religião, como mostraremos a seguir. Para melhor entendimento dos movimentos sociais da IEADB, trazemos uma breve história desse grupo religioso, que inclui mudanças de regras de comportamento e costumes ligados às mulheres. Em seguida, descrevemos as etapas do estudo feito por meio de análise de imagens e textos compartilhados no Instagram. Os achados apresentados sugerem negociações simbólicas que borram os limites estabelecidos pelas normas religiosas.

\section{Religião, consumo e dinâmica do desejo}

O filósofo Pierre Bourdieu $(1986,1991)$ ajuda-nos a compreender as relações de poder e a entre o religioso e o mundano por meio dos conceitos de campo, habitus e capital. Ele destaca o capital religioso entre diferentes tipos de capital. Segundo Bourdieu (1991), as condições que produzem a urbanização das sociedades e a divisão entre trabalho físico e intelectual são as mesmas que levam à constituição de um campo religioso autônomo e à necessidade de moralização e de sistematização das práticas religiosas. 0 capital religioso é aquele alienado dos leigos e concentrado nas mãos de especialistas que o utilizam, por exemplo, na gestão dos bens sagrados que podem ser modificados de forma a influir nas práticas e no habitus tanto dos religiosos quanto dos leigos. 0 habitus é uma disposição duradoura e generalizável para que as ações tenham uma conformidade (BOURDIEU, 1987 citado por VERTER, 2003ㄱ). Dessa forma, as regras impostas à prática religiosa se refletem tanto no comportamento de consumo religioso quanto no secular. Também o consumo secular e mundano pode se refletir naquele atrelado às condutas religiosas que são revistas de tempos em tempos como forma de gestão do capital religioso e de outros capitais, como sugere a história do movimento pentecostal (CAMPOS, 2005).

As igrejas podem também ser vistas como instituições de marketing nas quais os consumidores compreendem a religião como um conjunto de produtos e serviços, o que é denominado por marketização da religião. A capacidade socializadora de certas instituições religiosas vem diminuindo por causa dessa marketização e à destradicionalização da sociedade, que é a perda do poder das organizações que tradicionalmente ofereciam as referências de comportamento ideal para formação da identidade (MCALEXANDER et al., 2014). Os dogmas religiosos incluem, em geral, explícita indicação ou condenação de alguns itens de consumo, como alimentos, vestuário e adornos, cuja transgressão pode ter consequências espirituais ou punitivas da comunidade (JACOBS, 2007). 0 processo de destradicionalização trata da perda do poder das instituições de cobrar o cumprimento dessas regras, pois envolveria a expulsão desse membro do grupo, o que não é interessante por causa da marketização, que busca a adaptação da igreja ao seu público-alvo.

\footnotetext{
BOURDIEU, Pierre. Legitimation and structured interests in Weber's sociology of religion. Trad. Chris Turner. 1987, p. 119-136. In: WHIMSTER, Sam; LASH, Scott (eds.). Marx Weber: rationality modernity. England: Allen and Unwin, 1987.
} 
A profanização do sagrado e/ou a sacralização do profano que acontece com bens e serviços de consumo é analisada por Belk, Wallendorf e Shelly (1989) e tem o consumo em torno dos rituais de Natal ou do Dia de Ações de Graça como exemplos. Essa profanização do sagrado pode ser também observada pela evangelização por meio do rádio e da televisão, bem como pelo surgimento das celebridades evangélicas (O'GUINN; BELK, 1989).

McAlexander et al. (2014) investigaram as experiências no mercado de consumo de membros descontentes da Igreja de Jesus Cristo dos Santos dos Últimos Dias, comumente conhecidos como mórmons, e concluíram que eles enfrentam séria crise de identidade à medida que tentam refazer seu autoentendimento com novas formas de construção de identidade, em um mercado com o qual não se sentem familiarizados. 0 estudo sugere que ideologia religiosa e consumo são co-construtivos e inseparáveis em sua natureza.

O estudo de Sandikci e Ger (2010), por exemplo, mostra essa combinação de ideologia religiosa e consumo ao apresentar o modo como consumidoras conciliaram suas tradições culturais e religiosas com a moda laica, indicando, por pesquisa etnográfica, os novos significados atribuídos ao uso do véu por mulheres turcas de classe média e residentes em grandes centros urbanos, isto é, aproximando a utilização do véu da moda, deixando de ser uma prática desviante e estigmatizada para se tornar uma opção atraente e mesmo um hábito de vestuário comum para muitas mulheres. Nesse estudo, aparece um movimento inverso no qual acontece a profanização para redimir o sagrado, usando práticas do sistema da moda, como a personalização, para redimir o véu. Seguindo esse caminho, Miranda e Rocha (2016) buscam identificar elementos de moda com os quais consumidoras turcas constroem sua identidade, apesar dos elementos restritivos ao consumo ditados pela religião.

Também nos estudos de Sobh, Belk e Gressel $(2012,2014)$ foram pesquisados os hábitos de consumo de moda de jovens universitárias do Qatar e dos Emirados Árabes Unidos, países que, ao mesmo tempo que recebem grande contingente de estrangeiros, possuem renda ainda concentrada nas mãos dos cidadãos nativos e também onde a fé islâmica possui um rígido habitus quanto à simplicidade do vestuário feminino que rejeita a sensualidade; nesse caso, as informantes indicaram ter zelo pela própria cultura, mas também que sofrem pressões para assimilar a cultura global de consumo.

Já Belk, Ger e Askegaard (2005) discutem o papel do desejo no consumo por meio de experiências cotidianas em três diferentes culturas: Estados Unidos, Dinamarca e Turquia. 0 esquema conceitual proposto relaciona consumo e desejo a partir de um ciclo de auto sedução que conduz à reciclagem do desejo tão logo ele seja realizado; este, por sua vez, leva a transformações do consumo alimentadas pela esperança da satisfação. Desejo e esperança, assim, são estados relacionados, mas distintos, pois enquanto o desejo é a atração emocional por um objeto ou uma atividade inacessível, a esperança é a sensação de que tal desejo pode se realizar. Portanto, sem a esperança os desejos tornam-se meras fantasias impossíveis. 
O estudo de Rauf, Prasad e Ahmed (2018), por sua vez, revisitou Belk, Ger e Askegaard (2005), analisando o papel desempenhado pelo desejo no consumo a partir do pensamento de Jacques Lacan, para quem o desejo opera no nível subconsciente e tem um grande potencial disruptivo das relações sociais porque não respeita normas ou autoridade. Esses autores analisam a comunidade islâmica ortodoxa Tablighi Jamaat e partem do pensamento de Abu Hamid Muhammad Al-Ghazali, teólogo islâmico do século XI, para observar como religiões operam para disciplinar o desejo e preservar as relações sociais. O mecanismo consiste em ensinar que os desejos desse mundo afastam os fiéis da divindade e prejudicam sua vida no porvir, enquanto uma vida ascética tem o efeito inverso.

Em Rentas Vega (2019), há um ensaio baseado na teoria das identidades sociais para examinar como mulheres pentecostais norte-americanas usam as roupas a fim de gerenciar sua identidade religiosa e, indiretamente, sua identidade de gênero. A pesquisadora notou uma clara divisão de papéis entre homens e mulheres dentro da estrutura das igrejas, que se reflete em um código de vestuário binário (masculino e feminino). Além disso, atribui-se às fiéis a responsabilidade de evitar roupas que provoquem o desejo sexual nos homens, incitando-os ao pecado. Por fim, ela registra que a maneira peculiar e semelhante como os pentecostais se vestem reflete sua rejeição à moda como uma expressão da cultura secular e, ao mesmo tempo, o fato de se considerarem uma comunidade igualitária. No entanto, a pesquisa registra que as fiéis mais jovens estão negociando o direito de participar ativamente das igrejas e seguir a moda secular, evitando roupas consideradas masculinas ou sensuais - entendendo-se como sensualidade a exposição direta da pele.

Por fim, Cezar (2010) investigou como os preceitos da religião protestante radical orientam os princípios da moda das seguidoras de uma religiosidade evangélica extremada. Embora o discurso religioso seja de valorização das boas obras em detrimento da aparência, observou-se, na prática, uma grande preocupação em seguir um código de vestuário que reafirme sua identidade religiosa, orientado pelos princípios da aceitação da aparência natural como uma dádiva divina, da não incitação do desejo sexual nos homens e da preservação de uma clara distinção no vestuário entre homens e mulheres

Quanto à IEADB, foi possível localizar dois estudos que exploram sua influência nos hábitos de consumo de suas fiéis (ALVES, 2009, 2012; ALBUQUERQUE et al., 2018). Tais investigações sugerem que há uma negociação entre as normas da religião e os usos e costumes nas igrejas. Na pesquisa de Alves (2012), a distinção aparece mais como uma escolha do que como uma renúncia proposta pelas regras. A opção de segui-las ou não é reforçada pela aquisição de capitais sociais e culturais. Já o estudo de Albuquerque et al. (2018), que buscou compreender o significado do consumo de moda e vestuário gospel, sugere uma hibridização das regras assembleianas com a cultura fast-fashion (moda rápida). Para as informantes, o consumo da moda gospel é uma demonstração da beleza da mulher crente e uma afirmação de sua diferenciação das mulheres do mundo. 
E quanto ao universo digital? Como se dá a afirmação do discernimento das mulheres por meio da moda gospel no mundo informacional? Não podemos voltar a Bourdieu e às diferenças entre o religioso e o mundano pois ele não viveu em uma época com essas características. O filósofo Han Byung-Chul, em seu livro A sociedade da transparência (2017), fala da aceleração do tempo, que também aparece no ciclo da moda, no mundo informacional, e descreve a perda da transparência como consequência dessa aceleração, da linguagem e das imagens nas redes sociais, nas quais não existem espontaneidade nem liberdade, mas sim ações calculadas, direcionadas e controladas.

Para o filósofo, as pessoas substituem a comunicação pela busca da circulação da informação e de reações em cadeia, ou seja, likes, número de seguidores e de comentários positivos e elogiosos ou repostagens. Han fala que o excesso de exposição e de informações produz "um mundo desnudo e desavergonhado" (HAN, 2017, p. 15), o que parece se opor ao desejável para as religiões mais conservadoras, que possuem regras de comportamento e de estética. Ele comenta também sobre renunciar uma esfera privada que é substituída pela necessidade de exposição pública "sem qualquer pudor" (HAN, 2017, p. 109).

\section{Breve história da Assembleia de Deus no Brasil}

O movimento pentecostal surgiu nos Estados Unidos no início do século XX e foi rapidamente assimilado e difundido para diversas regiões (CAMPOS, 2005; FRESTON, 1995). 0 Brasil, assim como outros países, passava por um processo de modernização e urbanização e nem todos se sentiam beneficiados por ele; as camadas mais pobres da população ainda eram rurais, conservadoras, patriarcais e economicamente alijadas do mercado de consumo que se formava (ALENCAR, 2015; FRESTON, 1995).

A IEADB já surgiu como um movimento sectário e ascético que se propagou em todo o país seguindo as ondas migratórias da população. Em vez de obedecer a um modelo tradicional de igreja, a IEADB lançou-se ao encontro das necessidades da população mais humilde, propondo uma distribuição mais democrática do capital religioso. A falta de esperança na melhoria das condições de vida foi correspondida por uma ruptura que anunciava a volta de Cristo, inaugurando uma nova era de salvação. 0 elevado capital social, necessário para abandonar a religião tradicional católica e majoritária, era compensado pela inclusão em uma comunitas, na qual novos capitais culturais e sociais eram oferecidos. Ao mesmo tempo, a rejeição à sociedade contemporânea, percebida pelos fiéis como pervertida e da qual se sentiam excluídos, era convertida em repulsão à cultura secular que incluía, por exemplo, a moda (FERREIRA, 2015; PORTELA, 2012).

A proposta assembleiana foi bem recebida e, após 20 anos, a igreja já estava presente em todos os estados brasileiros, movimento que ficou conhecido como Primeira Onda Pentecostal ou Pentecostalismo Clássico, que foi seguida por mais duas ondas (ALENCAR, 2015; FRESTON, 1995). Na figura 1, apresentamos a diacronia da IEADB no contexto pentecostal no Brasil. 
FIGURA 1 - DIACRONIA DA IEADB NO CONTEXTO PENTECOSTAL BRASILEIRO

\section{O Pentecostalismo no Brasil em Três ondas}

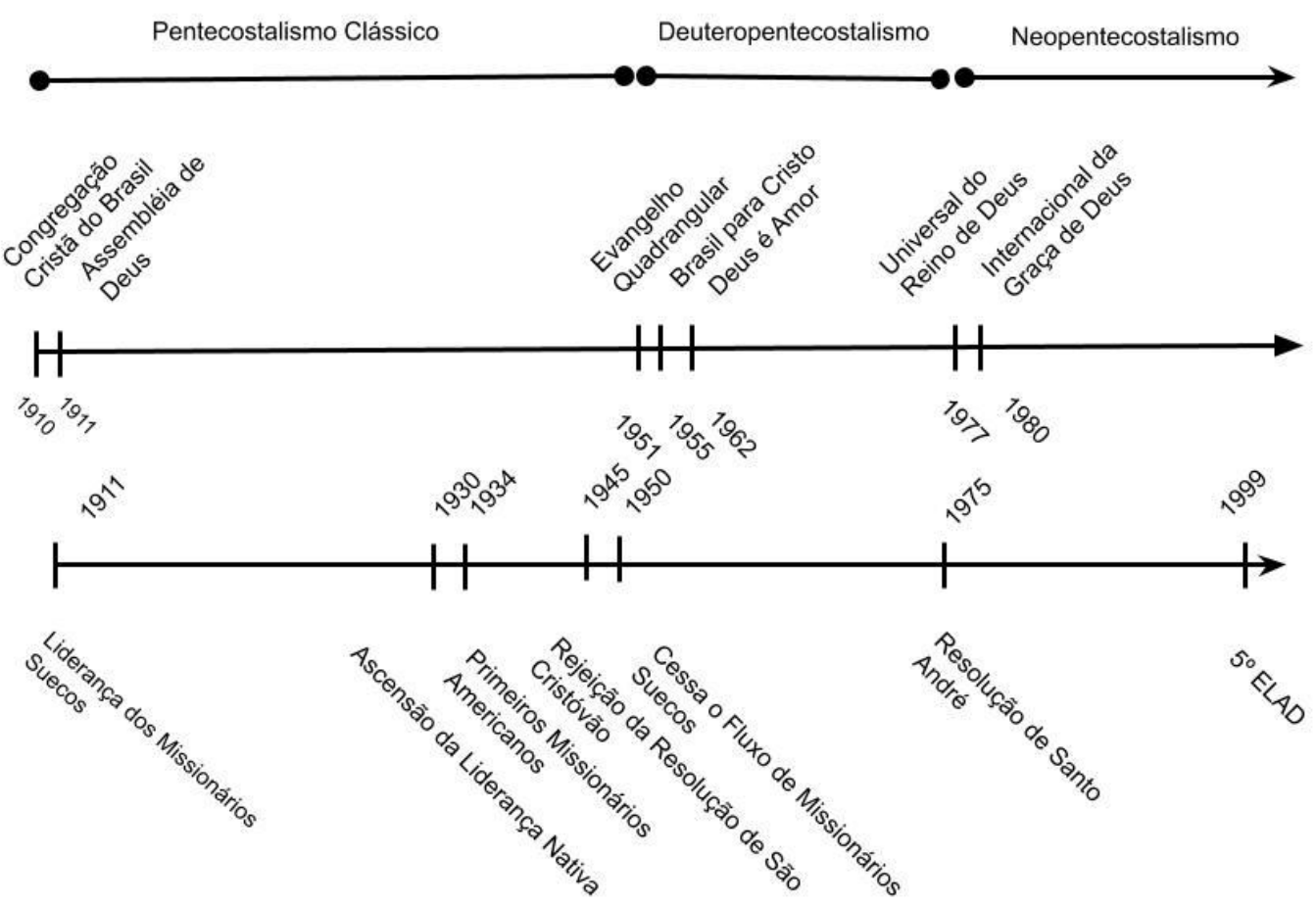

Influências Culturais e Regras sobre o Look na IEADB

FONTE: Construído a partir de informações de Fonseca, 2009a, 2009b; Freston, 1995.

Desde a sua fundação, a IEADB foi dirigida por missionários suecos, ainda que a maioria das igrejas locais fossem pastoreada por obreiros nativos. Porém, a partir de 1930, os brasileiros conquistaram autonomia cada vez maior, até que, em 1950, praticamente cessa a chegada de missionários suecos. Foi durante esse processo que surgiu a primeira tentativa de regulamentar os hábitos de consumo dos fiéis. Diante da falta de uma norma geral, a então influente Igreja de São Cristóvão (RJ) publicou, no jornal oficial da IEADB, uma norma de usose costumes de seus membros que ficou conhecida como A resolução de São Cristóvão (ver descrição no quadro 1). Essa determinação foi considerada excessivamente rigorosa e o presbitério da igreja teve de se retratar em uma edição posterior do mesmo jornal (FONSECA, 2009b).

A Segunda Onda Pentecostal ou Deuteropentecostalismo (figura 1), a partir de 1950, rompeu o isolamento social em que o movimento se encontrava e iniciou o uso dos meios de comunicação de massa (principalmente o rádio) e de espaços seculares, como tendas de circo, cinemas e teatros, para disseminar sua fé (ALENCAR, 2015; FRESTON, 1995). Somente no ano de 1975 a Assembleia de Deus chegou a uma resolução majoritária sobre usos $e$ costumes (ver Resolução de Santo André no quadro 1). Essa norma encontrou grande aceitação e vigorou de forma pacífica por mais de 20 anos (ALENCAR, 2015; FRESTON, 1995; FONSECA, 2009a, 2009b). 
A década de 1970 assistiu o surgimento da chamada Terceira Onda Pentecostal ou Neopentecostalismo (figura 1). As novas igrejas trouxeram uma mensagem mais utilitarista, prometendo a resolução dos problemas imediatos por meio da fé e difundindo a teologia da prosperidade. Ao mudar o foco para o tempo presente, as igrejas sancionaram a participação de seus fiéis no mercado de consumo. A liturgia mais próxima da cultura secular começou a ocupar um espaço cada vez maior no rádio e na televisão. A palavra inglesa gospel passou a identificar todo um conjunto de produtos e serviços dirigidos aos evangélicos. Essas mudanças atraíram um público que resistia aos rígidos costumes pentecostais.

No fim do século XX, a diversidade de opções de igrejas no campo pentecostal aumentou o poder de negociação dos fiéis no mercado de capitais religiosos. Ao mesmo tempo, um grupo de fiéis com maiores níveis de renda e educação formal passou a questionar normas ascéticas e sectárias da IEADB. Diante da concorrência, a IEADB decidiu flexibilizar as regras (ALENCAR, 2015; FRESTON, 1995). Em 1999, uma nova resolução foi proposta com o intuito de atualizações (ver 5o ELAD - Encontro de Líderes da Assembleia de Deus no quadro 1) que ainda vigoram como posição oficial. Cabe observar que as decisões doutrinárias sobre usos e costumes são tomadas pelos pastores, denominação hierárquica que não inclui mulheres (FONSECA, 2009a, 2009b). Como se pode notar, a partir do quadro 1, existe uma predominância de normas dirigidas às mulheres; tal fato foi determinante para a escolha desse grupo para o estudo que será descrito em suas etapas no próximo tópico. As condutas em negrito são as que foram interpretadas para esse estudo.

\section{QUADRO 1 - MUDANCAS DE NORMAS DE USOS E COSTUMES NA IEADB}

\begin{tabular}{|c|c|c|c|}
\hline Normas são dirigidas a: & $\begin{array}{c}\text { Resolução de São Cristóvão } \\
\text { (1945) } \\
\text { NORMAS }\end{array}$ & $\begin{array}{l}\text { Resolução de Santo André } \\
\text { (1975) NORMAS }\end{array}$ & 5을AD (1999) NORMAS \\
\hline Todos & & $\begin{array}{l}\text { - Não uso de aparelho de } \\
\text { televisão por causa da } \\
\text { qualidade dos programas } \\
\text { e proibição do consumo de } \\
\text { bebidas alcoólicas. }\end{array}$ & $\begin{array}{l}\text { - Não fazer mau uso dos meios } \\
\text { de comunicação: televisão, } \\
\text { internet, rádio, telefone. } \\
\text { - Não uso de bebidas } \\
\text { alcoólicas. }\end{array}$ \\
\hline Homens & & $\begin{array}{l}\text { - Não uso de cabelos } \\
\text { crescidos. }\end{array}$ & $\begin{array}{l}\text { - Não uso de cabelos crescidos } \\
\text { e de cortes extravagantes. }\end{array}$ \\
\hline Mulheres & $\begin{array}{l}\text { - Não raspar as sobrancelhas, } \\
\text { não ter o cabelo solto, cortado, } \\
\text { tingido, permanente ou outras } \\
\text { extravagâncias de penteado. } \\
\text { - Vestidos devem ser } \\
\text { compridos para cobrir o corpo } \\
\text { com pudor e modéstia: } \\
\text { sem decotes exagerados e } \\
\text { com mangas compridas. } \\
\text { - Recomenda-se o uso de } \\
\text { meias às esposas dos pastores, } \\
\text { anciãos, diácono e professoras } \\
\text { da Escola Dominical. }\end{array}$ & $\begin{array}{l}\text { - Não uso de traje masculino, } \\
\text { não uso de pinturas nos } \\
\text { olhos, nas unhas e em } \\
\text { outros órgãos da face. } \\
\text { - Não cortar os cabelos ou ter } \\
\text { as sobrancelhas alteradas. } \\
\text { - Não uso de minissaias e } \\
\text { “outras roupas contrárias } \\
\text { ao bom testemunho } \\
\text { da vida cristã". }\end{array}$ & $\begin{array}{c}\text { Não uso de roupas } \\
\text { peculiares aos homens. } \\
\text { - Não uso de cabelos curtos. } \\
\text { - Não uso de vestimentas } \\
\text { indecentes e indecorosas. } \\
\text { - Não uso de vestimentas } \\
\text { sem modéstia. } \\
\text { - Não uso exagerado de } \\
\text { pintura e maquiagem, } \\
\text { unhas e tatuagens. }\end{array}$ \\
\hline
\end{tabular}

FONTE: Construído a partir das informações de Fonseca (2009a e 2009b). 


\section{Sobre o estudo}

O protocolo de análise da imagem de moda proposto por Maciel e Miranda (2009) segue uma lógica de elementos de composição comuns em trajes e tem como referência o método de análise semiótica de imagens paradas de Penn (2002), no qual o investigador trabalha com um conjunto de instrumentais conceptuais para uma abordagem sistemática dos sistemas de signos a fim de descobrir como eles produzem sentido.

0 primeiro passo deste estudo foi a seleção do material a ser analisado, o que foi simplificado pelo acesso às fotos do Instagram por meio das hashtags que reúnem a comunidade assembleiana; o segundo foi identificar elementos presentes nas imagens recortadas da rede social; o terceiro momento envolveu níveis mais altos de significação que incluem a exploração das conotações de cada elemento e dos modos como eles se relacionam uns com os outros e a associação dos eixos culturais necessários para se ler o material selecionado; o quarto estágio foi o da descrição e da interpretação analítica das negociações simbólicas presentes nas imagens e nos textos, tendo em vista as normas a serem seguidas pelas mulheres assembleianas (ver quadro 1).

Esse tipo de estudo estabelece critérios de observação que possam identificar semelhanças e diferenças por meio de elementos identificados na composição das imagens. Essa análise possibilita a construção de uma lógica que vai além do tempo e do espaço, sendo seus critérios indicados por Maciel e Miranda (2009) no quadro 2, a seguir.

QUADRO 2 - CRITÉRIOS DE ANÁLISE

\begin{tabular}{|l|l|}
\hline 1 - FORMA & Pontos em comum na construção do traje - modelagem, comprimento, volumes das peças em análise. \\
\hline 2 - COR & Pontos em comum na predominância das cores e sua composição na peça ou no traje. \\
\hline $\mathbf{3}$ - MATERIAIS & $\begin{array}{l}\text { Pontos em comum nos materiais utilizados para confecção das peças, tais como tecidos e aviamentos; e } \\
\text { pontos em comum nos materiais usados para confecção de acessórios. }\end{array}$ \\
\hline $\mathbf{4}$ - COMPOSIÇÃo & $\begin{array}{l}\text { Pontos em comum na forma de compor as peças no traje; e pontos em comum entre o uso de acessórios, } \\
\text { mesmo que atualizados ou substituídos por outros símbolos de composição do traje. }\end{array}$ \\
\hline $\mathbf{5}$ - GESTUAL & Pontos em comum na forma de usar e de se comportar no momento da captação da imagem. \\
\hline
\end{tabular}

FONTE: Maciel e Miranda, 2009.

Nossa análise parte da resolução mais recente da IEADB com as normas de costumes direcionadas às mulheres e que repercutem no consumo de produtos de moda e beleza. Três princípios podem ser interpretados do texto: feminilidade, decência e modéstia.

0 primeiro, da feminilidade, está associado às normas que indicam que as mulheres assembleianas se abstenham de estéticas peculiares aos homens, tais como o uso de calças compridas e cabelos curtos (Rentas Vegas, 2009); o segundo princípio, o da decência, está vinculado à visão das mulheres como mais fracas, mais inclinadas à vaidade e, consequentemente, como uma porta de entrada para o pecado, como observou Fonseca (2009b). Esse 
segundo princípio abarca os elementos estéticos femininos, tais como vestuário, adereços e maquiagem associados à não decência ou à sedução.

0 terceiro e último preceito, o da modéstia, pode ser compreendido pela proibição da apresentação de um vestuário sem modéstia, como o uso de roupas, maquiagem, unhas e cabelos chamativos, além de tatuagem. Portela (2012) afirma que esse tipo de padronização - mulheres de saia/vestido e homens de terno - ajuda a nivelar as pessoas e a eliminar diferenças sociais, ou seja, sinalizam modéstia.

Assim sendo, para investigar as consumidoras assembleianas na aplicação desses três princípios foi necessário identificar mulheres com alguma representatividade no universo estimado em torno de 6 milhões de assembleianas (IBGE 2010) presentes em todos os estados do Brasil (Freston,1995). Segundo Caliandro (2018), a lógica muitos-para-muitos da Web 2.0 cria um ambiente interativo, no qual ocorre uma difusão em rede que se incorpora ao dia a dia das pessoas, colaborando para a construção de identidades e de laços sociais; o pesquisador observa ainda que, nas redes, as pessoas se revelam voluntariamente, o que apoia nossa escolha por realizar esta pesquisa com informações do Instagram.

Entendendo que no Instagram as hashtags são as ferramentas oferecidas aos usuários para classificar suas postagens em torno de temas de interesse comum (TERRACIANO, 2013), este estudo buscou, inicialmente, identificar as principais hashtags compartilhadas por mulheres evangélicas de forma mais ampla, a saber, aquelas que acompanhavam a postagem de imagens de outras evangélicas, sem definir a igreja, e que traziam associações mais ou menos diretas com a moda evangélica. Essas hashtags revelaram três tipos principais de atores: (i) hashtags com imagens associadas a marcas que produzem moda evangélica (\#meninacristã); (ii) hashtags vinculadas a igrejas evangélicas específicas (\#bleianas e \#ccb) e (iii) hashtags com relações mais gerais sobre mulheres ou moda (\#mulheresevangelicas e \#lookgospell).

Posto que a escolha da IEADB para este estudo está relacionada com a clara exposição de normas estéticas a serem seguidas, escolhemos duas hashtags, \#bleinas e \#assembleinasestilosas, para serem acompanhadas durante três meses; feito isso, decidimos analisar apenas as imagens selecionadas a partir da hashtag \#bleianas - embora a \#assembleianasestilosas seja a que possui o maior número de postagens -, pois apresentava uma maior proporção de postagens de perfis individuais em relação às hashtags de anúncios de fornecedores, principalmente ligados à moda, e postagens de consumidoras não identificadas com a IEADB.

O compartilhamento de diferentes hashtags acompanhadas das imagens postadas, que pode incluir a identificação de diferentes igrejas evangélicas junto de uma mesma foto, sugere que essas mulheres seguem um código de vestuário semelhante ou participam de uma mesma negociação simbólica. Ainda assim, de forma a nos mantermos coerentes com a escolha da IEADB, decidimos estabelecer um critério para a seleção das mulheres: elas deveriam ter assumido a filiação à IEADB de forma explícita no seu perfil e/ou deveriam mostrar fotos das igrejas frequentadas - que poderiam ser identificadas como da IEADB -, e/ou ainda deveriam compartilhar apenas hashtags ligadas à Assembleia de Deus, tais como \#bleianas, \#bleianasestilosas e \#jovensbleianas. Para que a seleção não tivesse uma representatividade regional, selecionamos mulheres de diferentes estados brasileiros. 
0 quadro 3 apresenta as dez mulheres influenciadoras digitais que tiveram seus perfis analisados. Entre as 3.907 imagens disponíveis em postagens no Instagram das dez religiosas analisadas, três delas foram escolhidas para serem apresentadas neste artigo por reunirem elementos representativos das demais imagens.

\section{QUADRO 3 - INFLUENCIADORAS DIGITAIS ASSEMBLEIANAS}

\begin{tabular}{|c|c|c|c|c|}
\hline Nome do perfil & UF & $\begin{array}{l}\text { Número de } \\
\text { postagens }\end{array}$ & $\begin{array}{l}\text { Número de } \\
\text { seguidores }\end{array}$ & Descrição no perfil \\
\hline monikhotzhotz & $\mathrm{PE}$ & 47 & 15.700 & $\begin{array}{l}\text { Blogueira, digital influencer, cabeleireira, namorando, } \\
\text { modelo fotográfica, assembleiana IEADPE }\end{array}$ \\
\hline Cantorakamyllasantos & GO & 2.937 & 12.800 & $\begin{array}{l}\text { Influencer cristã, cantora, pastora, preletora, “amo } \\
\text { cantar e falar de Jesus é minha paixão", moda cristã, } \\
\text { Goiânia }\end{array}$ \\
\hline rohannapaulino & $\mathrm{RN}$ & 118 & 6.921 & $\begin{array}{l}\text { Cristã, nordestina, noiva, direito@uernoficial@fad_ } \\
\text { uern, técnic. de enfermagem @ Universidade Potiguar }\end{array}$ \\
\hline claudialima.oficialll & PI & 256 & 6.305 & $\begin{array}{l}\text { "Perfil sobre o que ele fez em mim", \#cristã IEAD, } \\
\text { Picos/Piauí, esposa de @carlosantoniosantos, insta de } \\
\text { alto ajuda (sic.) @curaalma22 }\end{array}$ \\
\hline Juliene.limaoficial & $\mathrm{AL}$ & 43 & 5.510 & $\begin{array}{l}\text { MKT DIGITAL @juiliene.oficial.2, “Estabeleça a } \\
\text { intimidade, entenda o propósito e aumente a renúncia”, } \\
\text { cristã, blogueira }\end{array}$ \\
\hline Resampaio00 & SP & 180 & 5.368 & $\begin{array}{l}\text { Moda cristã, Itupeva/Jundiaí SP, dicas/ look/ moda } \\
\text { modesta, mãe de uma princesa e um príncipe, AD } \\
\text { Madureira, Cristã. }\end{array}$ \\
\hline _joyce_figueired0 & MA & 45 & 4.604 & $\begin{array}{l}\text { Moda Cristã, blogueira, Maranhão/ Gov. Edison Lobão, } \\
2002 \text { | Assembleia de Deus COMADESMA. }\end{array}$ \\
\hline _tamiryssouza & PR & 29 & 3.042 & $\begin{array}{l}\text { 17y, Adrianópolis-PR, Cristã, Palavra “Porque para } \\
\text { Deus nada é impossível” }\end{array}$ \\
\hline liviamaiacavalcante12 & $\mathrm{CE}$ & 24 & 2.627 & $\begin{array}{l}\text { "Porque Ele vive, eu posso crer no amanhã", serva do } \\
\text { rei, assembleiana, pentecostal, tec. de Adm. } 1 / 3 \text {, futura } \\
\text { médica, } 17 / 08 / 2004 \text {. }\end{array}$ \\
\hline Anatalytalim & $\mathrm{PA}$ & 278 & 1.468 & $\begin{array}{l}19 \text { anos, cristã assembleiana, acadêmica de contábil } \\
\text { (sic.) e pedagogia, youtuber cristã }\end{array}$ \\
\hline TOTAL & & 3.957 & 64.345 & \\
\hline
\end{tabular}

\section{As negociações simbólicas}

Encontramos no Instagram expressões culturais compartilhadas capazes de produzir diversas subjetividades de aproximação e de distanciamento das normas anotadas da comunidade religiosa IEADB. Essa rede social projeta identidades religiosas, mas também reflexões que abrangem a difusão comercial da moda. Muitas imagens foram selecionadas de forma a identificar os três eixos de negociações simbólicas definidos para a investigação: negociações com a feminilidade, negociações com a decência e negociações com a modéstia. 


\section{Negociando com a feminilidade}

Quando analisamos as fotos postadas no perfil "rohannapaulino", encontramos dois grupos distintos de imagens: o primeiro com fotos dentro da igreja, que seguem as recomendações de vestuário assembleiano, e o segundo, com imagens que retratam uma vida secular na qual Rohanna se veste de acordo com a moda mundana, com saias acima do joelho, blusas sem alça e calças compridas. Também foi possível diferenciar as hashtags compartilhadas nos dois contextos. Quando segue as normas indicadas pela igreja, ela usa aquelas que dão pertencimento à sua igreja, tais como \#bleinas e \#ieadern. Quando se afasta das regras, não aparecem hashtags que fazem referência à religião.

FIGURA 2 - NEGOCIANDO COM A FEMINILIDADE

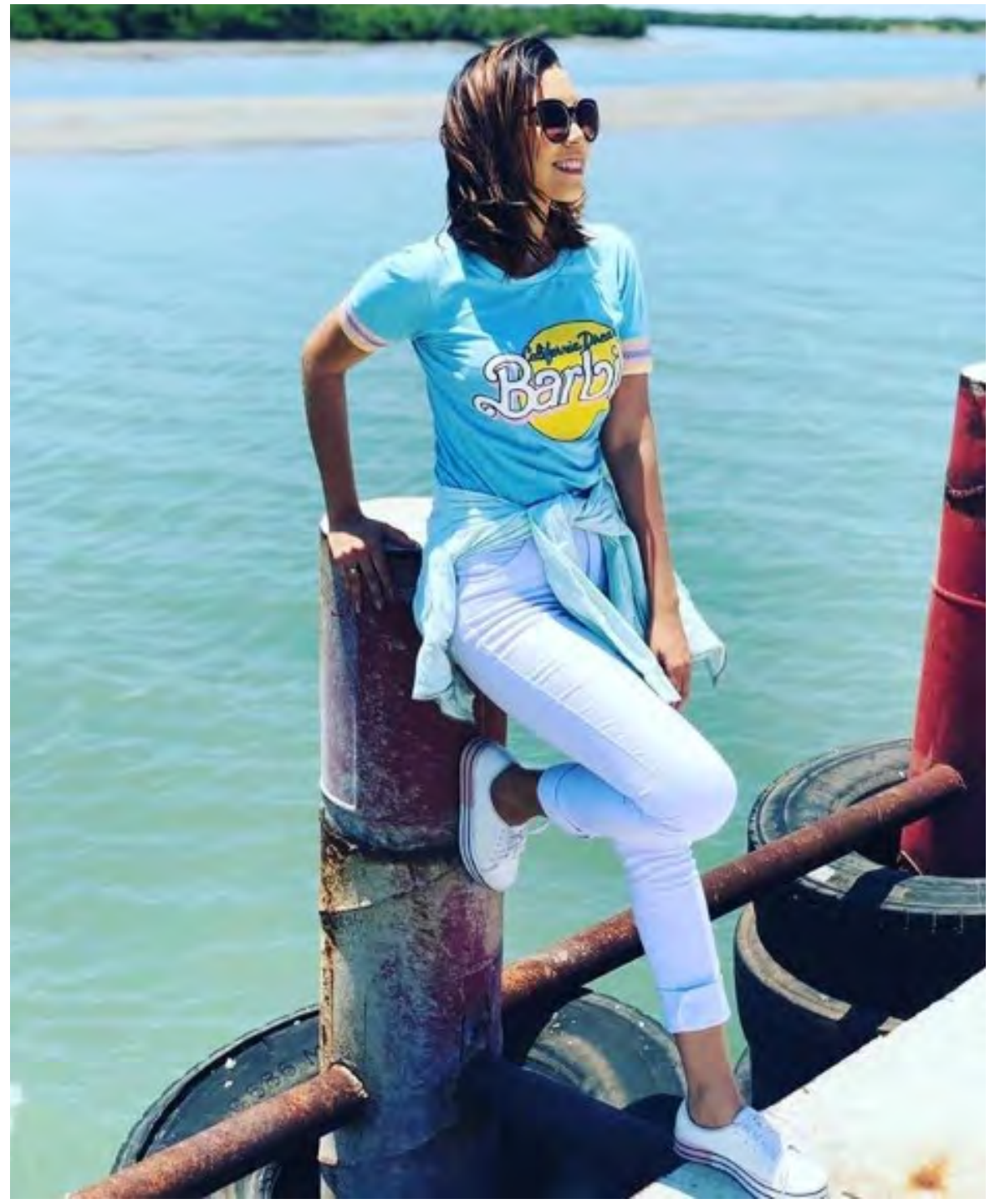

FONTE: https://www.instagram.com/p/B2_0iizJelF/ capturado às 22h36min do dia 29 de junho de 2020.

Texto: "Se você parar por um momento irá vê (sic) toda beleza que há no mundo (ROHANNA, 2020). 
A foto escolhida traz apenas hashtags que fazem referência ao local das fotos (\#portodomangue, \#portodomanguern). A imagem com a luminosidade do sol revela o contato alegre com a natureza sem qualquer referência religiosa. Esse ambiente da natureza, fora do contexto sagrado da igreja, participa da negociação simbólica de seu look que quebra a regra da feminilidade com o uso de calças compridas e do corte mais curto dos cabelos. Localizamos outras imagens de assembleianas vestindo calças compridas no contexto que retrata atividades de trabalho ou de lazer mas, durante o período de pesquisa, foram raras as imagens encontradas de uso de calças compridas em ambiente religioso, o que pode sugerir que na igreja, local privado e sagrado, o uso de roupas consideradas masculinas continua fora dos limites estabelecidos pelos pentecostais.

Além disso, o Instagram, local público, permite negociar aspectos considerados pelas normas como "peculiares aos homens". Uma possível explicação para esse comportamento está no fato de que, embora homens e mulheres já desempenhem as mesmas funções na vida secular, a distribuição de papéis dentro da IEADB ainda segue uma lógica binária entre eles, e as diferentes maneiras de vestir refletem a percepção de que o vestuário dentro do ambiente religioso deve respeitar essa lógica.

Nesse sentido, de acordo com a Resolução de Santo André, os cabelos na altura dos ombros seriam inadequados tanto para os homens quanto para as mulheres porque a eles eram vedados os "cabelos crescidos" e a elas era proibido o "corte de cabelos". No entanto, o 5응 ELAD veda às fiéis apenas o uso de "cabelos curtos", mantendo a proibição dos "cabelos crescidos" para os homens, o que tornou subjetiva a definição do limite entre o "curto" e o "crescido". Cabelos longos são intencionalmente destacados nas imagens pesquisadas, sugerindo sua importância como afirmação da feminilidade e da identidade religiosa. Por outro lado, o uso de cabelos cortados na altura dos ombros, como na foto analisada, demonstra uma negociação de limites e um questionamento dessa estética binária. 0 quadro 4 a seguir descreve e interpreta os cinco critérios nas três dimensões de negociação presentes na postagem.

QUADRO 4 - NEGOCIANDO COM A FEMINILIDADE

\begin{tabular}{|c|c|c|c|}
\hline \multirow{2}{*}{ FORMA } & Calça justa e de cintura alta. & Justo, mas coberto pelo casaco. & Formas simples e básicas. \\
\hline COR & Tons pastel. & $\begin{array}{c}\text { Cores pastéis e estampas } \\
\text { infantis que denotam inocência, } \\
\text { ingenuidade. }\end{array}$ & $\begin{array}{c}\text { Os tons das roupas são leves e } \\
\text { discretos. }\end{array}$ \\
\hline MATERIAIS & Malha na camisa e brim nas calças. & $\begin{array}{c}\text { D brim e a malha permitem } \\
\text { que as formas do corpo sejam } \\
\text { reveladas. }\end{array}$ & $\begin{array}{c}\text { Tecidos que conotam a simplicidade } \\
\text { e o cotidiano. Sendo o brim } \\
\text { conhecido como tecido de trabalho. }\end{array}$ \\
\hline COMPOSIÇÃO & $\begin{array}{c}\text { A forma e o material de conotação } \\
\text { masculina são suavizados pelas cores } \\
\text { e formas femininas, provocando a } \\
\text { negociação simbólica. }\end{array}$ & $\begin{array}{c}\text { As cores e o casaco negociam com } \\
\text { o justo da forma, produzindo a } \\
\text { conotação de decência. }\end{array}$ & $\begin{array}{c}\text { A modéstia está presente na } \\
\text { composição geral do look, } \\
\text { sendo um reforço desse valor de } \\
\text { mulher cristã negociando com a } \\
\text { feminilidade e a decência. }\end{array}$ \\
\hline GESTUAL & $\begin{array}{c}\text { A postura meiga e o olhar sonhador } \\
\text { que fixa o horizonte e não enfrenta } \\
\text { a câmera denotam suavidade no } \\
\text { cenário que dialoga com a natureza, } \\
\text { mar, deck (viagens, olhar para o } \\
\text { futuro, otimismo). }\end{array}$ & $\begin{array}{c}\text { A postura busca esconder a } \\
\text { parte debaixo do corpo. Os } \\
\text { braços abertos negociados na } \\
\text { composição pela gola sem decote } \\
\text { da camiseta. }\end{array}$ & $\begin{array}{c}\text { atitude contemplativa reforçam o } \\
\text { valor da modéstia. }\end{array}$ \\
\hline
\end{tabular}




\section{Negociando com a decência}

A dona do perfil "claudialima.oficialll" aparece nas fotos vestida dentro dos padrões assembleianos: blusas e vestidos sem decotes acentuados, que cobrem os ombros e saias com comprimento pelo menos até os joelhos, sem fendas ou transparências. Claudia possui várias fotos em seu Instagram nas quais aparece no ambiente religioso cantando, pregando, orando, com a Bíblia na mão e, às vezes, também está ao lado do marido. Essas fotos sugerem que Claudia possui capital religioso que pode conferir a ela flexibilidade para transitar dentro ou fora dos limites de seu habitus religioso, o que pode dar origem a ganho de mais capital social como sugere o texto que acompanha a foto.

\section{FIGURA 3 - NEGOCIANDO COM A DECÊNCIA}

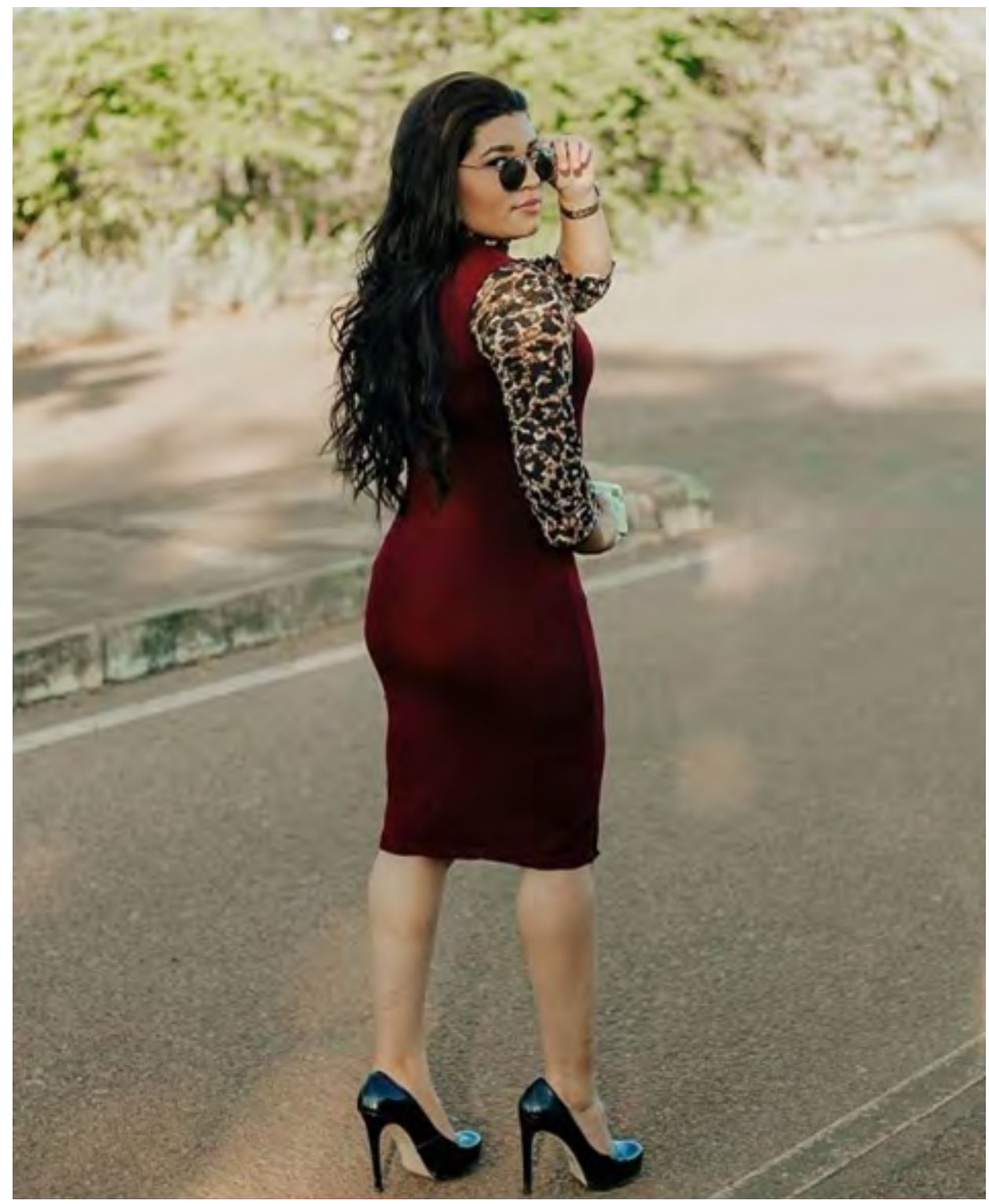

FONTE: https://www.instagram.com/p/CBaxkPEBpVM/ capturado às 21h56min do dia 29 de junho de 2020. 
Texto: “Não é preciso ser curto, e nem tão pouco vulgar, para ser bonito $\bigcirc$ (CLAUDIA, 2020).

Existe aqui uma negociação simbólica entre forma, cor e materialidade para manter o valor de decência e, embora as regras formais concernentes esse princípio e à feminilidade tenham sido cumpridas na imagem postada, Claudia provoca comentários como "Que mulherão é esse?! - OO'. No momento em que foi finalizada a busca por imagens, essa postagem já havia recebido 608 curtidas e 125 comentários elogiosos, tais como "Nossa que perfeição (20), "amei sua linda" e "Deusa -iv". Não obstante esse perfil tenha sido selecionado por meio da hashtag \#bleianas, tal hashtag não foi mencionada nessa foto, na qual anotamos \#assembelianasestilosas, \#photography, \#photo, \#cristã, \#modelocristã, \#modacristã, \#instacristao. Chama nossa atenção também as associações com estilo, moda e modelo.

Salienta-se que muitas fotos selecionadas pelo estudo, inclusive as tiradas dentro de igrejas, mostram vestidos, saias e blusas justos, com tecidos colantes e até transparentes, que realçam as formas do corpo, sem que fossem recebidos qualquer tipo de comentário crítico. Dessa forma, a negociação simbólica do princípio da decência acontece quando roupas justas, tecidos que revelam as formas do corpo e a livre escolha de cores e estampas são utilizados ao mesmo tempo que se segue a norma que não permite roupas curtas ou decotadas e/ou que mostrem diretamente a pele.

0 quadro 5 a seguir refere-se à postagem e descreve e interpreta os cinco critérios nas três dimensões de negociação.

QUADRO 5 - NEGOCIANDO COM A DECÊNCIA

\begin{tabular}{|c|c|c|c|}
\hline & FEMINILIDADE & DECÊNCIA & MODÉSTIA \\
\hline FORMA & Vestido e cintura marcada. & $\begin{array}{l}\text { Longo, fechado e justo. Blusa } \\
\text { por baixo para esconder ombro } \\
\text { e braços. }\end{array}$ & Formas básicas. \\
\hline COR & $\begin{array}{l}\text { Cor vinho e estampa animal de } \\
\text { onça. }\end{array}$ & $\begin{array}{c}\text { Combinação da cor vinho com } \\
\text { a estampa de onça. }\end{array}$ & As cores fortes e chamativas. \\
\hline MATERIALIDADE & Tecidos colantes ao corpo. & $\begin{array}{l}\text { O tecido revela as formas do } \\
\text { corpo. }\end{array}$ & Tecidos simples. \\
\hline COMPOSIÇÃO & $\begin{array}{l}\text { Feminilidade presente na } \\
\text { forma, nas cores e nos tecidos e } \\
\text { acentuada pelos cabelos longos e } \\
\text { pelos sapatos de salto alto. }\end{array}$ & $\begin{array}{l}\text { A negociação da decência se } \\
\text { dá entre o vestido longo e a } \\
\text { blusa de mangas compridas, } \\
\text { apesar do corte ajustado } \\
\text { e dos tecidos colantes. }\end{array}$ & $\begin{array}{l}\text { Apesar dos tecidos serem simples, a } \\
\text { combinação de cores é chamativa e } \\
\text { os sapatos têm saltos altos e finos. } 0 \\
\text { cenário de estrada denota liberdade, } \\
\text { caminho a ser percorrido. }\end{array}$ \\
\hline GESTUAL & $\begin{array}{c}\text { A postura destaca os cabelos } \\
\text { longos. }\end{array}$ & $\begin{array}{l}\text { O ângulo da foto destaca o } \\
\text { corpo. }\end{array}$ & $\begin{array}{c}\text { O olhar por cima dos óculos escuros é } \\
\text { de confrontação. }\end{array}$ \\
\hline
\end{tabular}

\section{Negociando com a modéstia}

0 perfil "cantorakamillasantos", construído há 11 anos, possibilitou uma análise de mudanças das imagens postadas ao longo do tempo. Inicialmente, prevalecem imagens de atividades eclesiásticas, mas, progressivamente, elas se modificam e passam a mostrar looks 
que se distanciam das normas pentecostais e se aproximam da moda mundana, o que sugere um processo de acumulação de capital cultural e religioso que permitiu a combinação da moda secular com o habitus pentecostal. A postagem analisada celebra a conquista de 11 mil seguidores e mostra um contraste criado pela própria Kamila nas duas fotos lado a lado, que traduzem o percurso que a levou a se auto definir como "influencer cristã". A sua trajetória também é narrada em texto que acompanha as imagens reproduzidas a seguir.

FIGURA 4 - NEGOCIANDO COM A MODÉSTIA

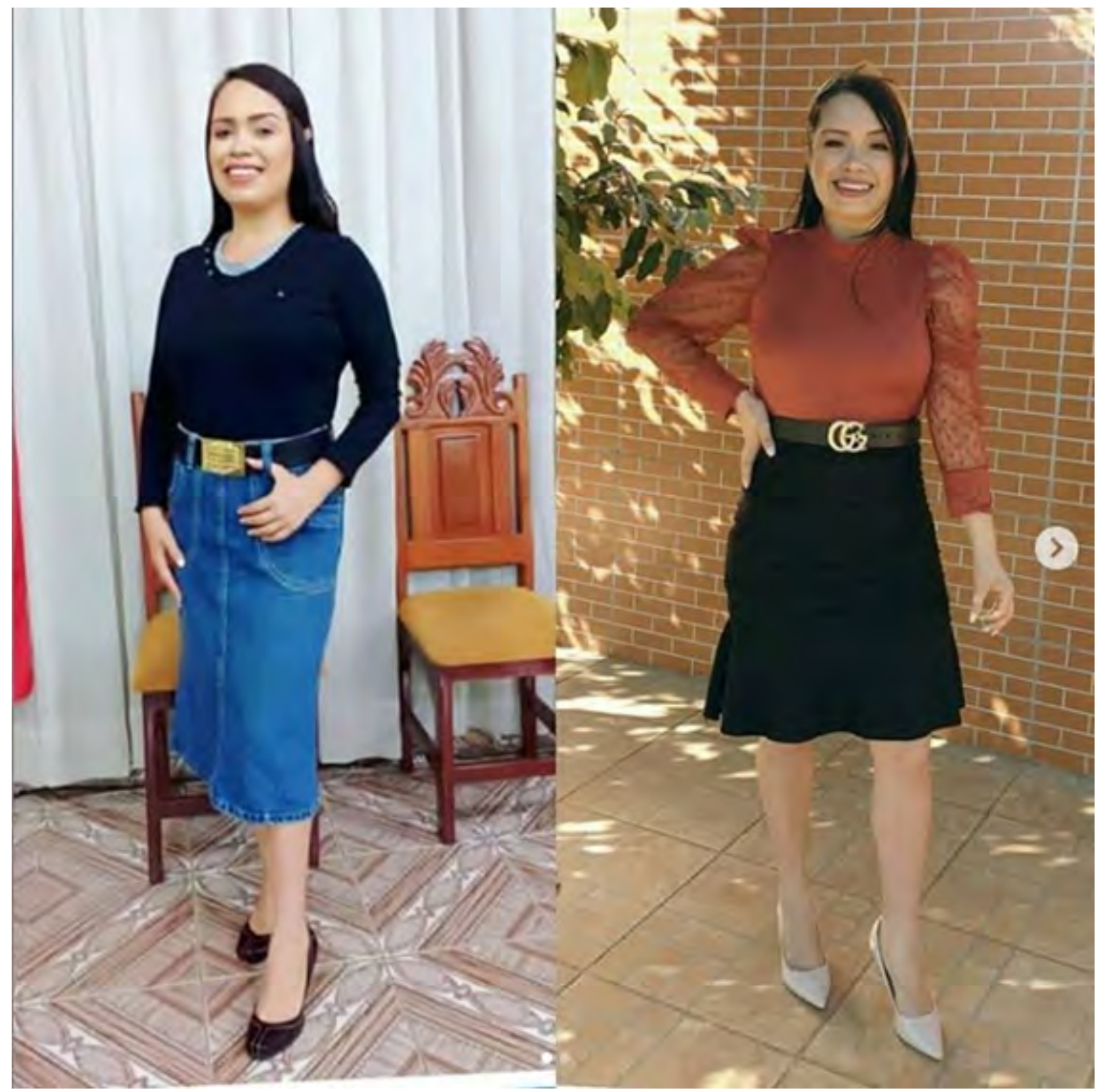

FONTE: https://www.instagram.com/p/CBO7VpPAjW4/ capturado às 15h22min do dia 29 de junho de 2020. 
Texto:

Você tem um S O N H O? vou contar mais um pouco sobre a minha história.....

A minha trajetória sempre foi espinhosa! Passei por muitos momentos difíceis na minha vida até chegar aqui. Me lembro de um dia ir a um culto para louvar, chegando na igreja vi tantas mulheres bonitas, e eu olhei pra mim e mi vi tão feia! -0: Tao desarrumada perto delas, me senti um lixo naquele dia! Deus já me provou de várias maneiras! Sei o que é faltar alimento em casa! Sei o que é querer uma roupa nova e não ter dinheiro pra comprar! Sempre fui uma menina sonhadora e por ser assim muitos me jugam por sonhar demais! Alguns não deram nada por mim, duvidaram do que Deus tinha na minha vida, riram, zombaram e disseram que eu nunca ia chegar a lugar algum.

Faz quase 11 anos que saí da minha Terra Manaus Am e vim pra Goiânia, aqui cheguei debaixo da promessa de que Deus mudaria a minha história @aqui eu e meu esposo fomos muito provados! Mais o tempo de honra chega! A recompensa por ser fiel a Deus chega! Hoje Deus tem me dado condições de ter coisas, de comprar coisas, de poder investir no meu sonho. Tenho muito sonhos mais um deles já está se realizando que é ser uma INFLUENCER 숭 Deus sempre honra aqueles que não desisti! Aqueles que perseveram! Mesmo que doua mesmo que vc tenha que chorar saiba, tudo valerá a pena! Tem um Deus no céu escrevendo a tua história! Assim como eu estou vencendo vc tbm vai vencer!! Continua!! Deus vai mudar a sua história (sic). (KAMILA, 2020)

A narrativa da história na igreja se inicia com "sonhos" e "promessas" a serem alcançados em meio a uma situação que a impingia a ter modéstia. Ela fala de problemas financeiros, da dificuldade de ter roupas novas, de que se sentia "feia", "um lixo" frente às mulheres bonitas e arrumadas que encontrava nos cultos. Comenta do sentimento de descrença da comunidade em relação às suas possibilidades. Mas também conta que as conquistas chegam e chega "o tempo de honra" com "recompensa" por ter "sido fiel e louvado a Deus". Após 11 anos, a história, que havia iniciado com modéstia, dá lugar à conquista de "comprar coisas", "ter coisas" e assim "realizar um sonho" ao alcançar a posição de influencer.

A nova condição dá lugar a uma transformação: a primeira foto mostra uma estética mais convencional, como o uso de saia jeans mais comprida, que não marca o corpo, blusa lisa de mangas compridas, sapato simples e cabelos longos apresentados de forma natural. Na segunda foto, mais recente, há uma mudança de look: a saia é justa, mais curta e com babado, a blusa de manga ligeiramente bufante com tecido transparente, o cinto marca mais a cintura, os sapatos possuem salto mais alto e bico fino e os cabelos estão repicados e com uma fita turbante.

A segunda foto, portanto, sugere que Kamila negocia o princípio da modéstia sem quebrar as normas. 0 texto construído a partir do conceito de testemunho termina com incentivos às suas influenciadas de persistirem para vencer, "assim como eu estou vencendo".

Os comentários que se seguem à postagem das fotos comparativas e do texto explicativo trazem elogios habituais, a partir principalmente da imagem, como "linda" e "princesa", ou trazem "bênçãos" diante da leitura do texto como: "Deus fiel, que testemunho forte amada. você vai além por que é batalhadora e merece o melhor dessa terra $\odot$ ”. 
0 quadro 6 a seguir descreve e interpreta os cinco critérios nas três dimensões de negociação que emergem nessa postagem. Ressalte-se que embora essa imagem tenha sido selecionada para análise também a partir da \#bleianas, as hashtags compartilhadas parecem se dividir entre aquelas que se ligam ao texto, tais como \#testemunho, \#sonhorealizado e \#gratidãomedefine, e aquelas que se associam às imagens postadas como \#lookcristao, \#lookdemulher e \#princesadejesus.

QUADRO 6 - NEGOCIANDO COM A MODÉSTIA

\begin{tabular}{|c|c|c|c|}
\hline & FEMINILIDADE & DECÊNCIA & MODÉSTIA \\
\hline \multirow[b]{2}{*}{ Forma } & $\begin{array}{l}\text { Antes: } \\
\text { saia e blusa com } \\
\text { caimento reto. }\end{array}$ & $\begin{array}{l}\text { Antes: gola alta, mangas compridas e } \\
\text { saia abaixo do joelho. }\end{array}$ & $\begin{array}{l}\text { Antes: } \\
\text { formas retas e simples. }\end{array}$ \\
\hline & $\begin{array}{c}\text { Depois: } \\
\text { saia drapeada evasê e blusa com } \\
\text { cintura marcada. }\end{array}$ & $\begin{array}{l}\text { Depois: } \\
\text { a saia fica acima dos joelhos e as } \\
\text { mangas continuam compridas. }\end{array}$ & $\begin{array}{c}\text { Depois: } \\
\text { saia drapeada evasê e blusa de } \\
\text { mangas bufantes. }\end{array}$ \\
\hline \multirow[b]{2}{*}{ Cor } & $\begin{array}{l}\text { Antes: } \\
\text { blue jeans com preto. }\end{array}$ & $\begin{array}{l}\text { Antes: } \\
\text { tecidos opacos. }\end{array}$ & $\begin{array}{l}\text { Antes: } \\
\text { cores opacas e discretas. }\end{array}$ \\
\hline & $\begin{array}{c}\text { Depois: } \\
\text { ocre e preto. }\end{array}$ & $\begin{array}{c}\text { Depois: } \\
\text { tecidos opacos, mangas ficam } \\
\text { transparentes. }\end{array}$ & $\begin{array}{l}\text { Depois: } \\
\text { cores cintilantes. }\end{array}$ \\
\hline \multirow{2}{*}{ Materialidade } & $\begin{array}{l}\text { Antes: } \\
\text { jeans e malha. }\end{array}$ & $\begin{array}{l}\text { Antes: } \\
\text { jeans e malha. }\end{array}$ & $\begin{array}{l}\text { Antes: } \\
\text { jeans e malha. }\end{array}$ \\
\hline & $\begin{array}{l}\text { Depois: } \\
\text { Renda. }\end{array}$ & $\begin{array}{l}\text { Depois: } \\
\text { crepe e renda transparente. }\end{array}$ & $\begin{array}{l}\text { Depois: } \\
\text { crepe cintilante e renda. }\end{array}$ \\
\hline \multirow[b]{2}{*}{ Composição } & $\begin{array}{c}\text { Antes: } \\
\text { embora os materiais, as cores e } \\
\text { o corte reto sejam masculinos, a } \\
\text { saia, a blusa, os cabelos longos } \\
\text { e o sapato de salto alto são } \\
\text { femininos. }\end{array}$ & $\begin{array}{c}\text { Antes: } \\
\text { formas e cores discretas. }\end{array}$ & $\begin{array}{c}\text { Antes: } \\
\text { forma, cores e tecidos são } \\
\text { discretos, a maquiagem é suave e o } \\
\text { salto não muito alto. }\end{array}$ \\
\hline & $\begin{array}{c}\text { Depois: } \\
\text { tudo emana feminilidade, } \\
\text { conjunto de saia e blusa com } \\
\text { cinto que realça a cintura, as } \\
\text { cores, a materialidade dos } \\
\text { tecidos, os cabelos longos e o } \\
\text { sapato com salto mais alto que } \\
\text { o anterior. }\end{array}$ & $\begin{array}{l}\text { Depois: } \\
\text { a saia mais curta e as mangas } \\
\text { transparentes da blusa demonstram } \\
\text { negociação com a decência. }\end{array}$ & $\begin{array}{l}\text { Depois: } \\
\text { Saia mais curta, cintura marcada } \\
\text { pelo cinto, manga bufante de } \\
\text { renda que remete à nobreza, } \\
\text { tecidos cintilantes, salto } \\
\text { mais alto, maquiagem mais } \\
\text { acentuada, faixa nos cabelos } \\
\text { negociam com a modéstia. }\end{array}$ \\
\hline \multirow[b]{2}{*}{ Gestual } & $\begin{array}{c}\text { Antes: } \\
\text { feminilidade simples e } \\
\text { espontânea. }\end{array}$ & $\begin{array}{l}\text { Antes: } \\
\text { gestual e olhar ingênuos. }\end{array}$ & $\begin{array}{l}\text { Antes: gestual e olhar simples. A } \\
\text { cadeira senhorial e as cortinas } \\
\text { sugerem que a foto foi tirada no } \\
\text { interior de uma igreja. }\end{array}$ \\
\hline & $\begin{array}{l}\text { Depois: } \\
\text { feminilidade elaborada, com } \\
\text { gestual proposital e olhar } \\
\text { confiante. }\end{array}$ & $\begin{array}{l}\text { Depois: } \\
\text { gestual e olhar mais autoconfiantes, } \\
\text { mas ainda decentes. }\end{array}$ & $\begin{array}{c}\text { Depois: } \\
\text { gestual proposital e sofisticado. } \\
\text { O cenário parece ser um espaço } \\
\text { privado ao ar livre. }\end{array}$ \\
\hline
\end{tabular}


Nesse caso, não foi possível identificar tensões ou resistências expressas nos comentários que seguiam as imagens e os textos postados no Instagram, o que pode indicar que o conteúdo analisado propõe uma negociação simbólica sem expectativa de recrudescimento desse movimento de flexibilização dos princípios tradicionais observado.

Vimos que os três perfis sugerem looks coloridos e variados, transmissores de prosperidade e até sensualidade. Ainda que não sigam as normas, as imagens e os textos postados sugerem engajamento e proteção aos preceitos que interpretamos sobre as regras. Mas este estudo, assim como observado por Albuquerque et al. (2018), mostra uma mudança no tradicional habitus pentecostal cujos princípios são a feminilidade, a decência e a modéstia. A busca de homogeneidade no vestuário feminino do passado, caracterizada, por exemplo, por roupas e adereços mais sóbrios, vem perdendo espaço, como demostraram as imagens analisadas. Observamos também a forte presença de marcas posicionadas como moda cristã ou gospel, tais como Nayglamour, Hapuk Cianorte, Altamoda Princesas Cristãs. As marcas e os looks indicam a construção da identidade, da afirmação e da diferenciação da beleza das mulheres assembleianas que, junto com o vestuário da moda, recorrem mais livremente a produtos de beleza, tais como esmaltes e maquiagem.

\section{Considerações finais}

Para o filósofo coreano Byung-Chul Han (2017), a sociedade disciplinar de Foucault dá lugar à sociedade da performance ou do desempenho. Sob essa perspectiva, entendemos que as assembleianas analisadas se rendem à comunidade digital, que pressiona por exposição e por produção de imagens e narrativas capazes de chamar atenção. Fazem-no, porém, de tal modo que imagens e comentários elogiosos não denotem sinais de que estão negociando ou rompendo regras. Nesse sentido, o filósofo coreano fala ainda da aceleração das mídias digitais que promovem uma sensação de proximidade e intimidade capaz de inibir críticas que precisam de certo distanciamento.

Com esse estudo, mostramos uma ausência de comentários negativos e a presença de muitos elogiosos diante de imagens femininas que burlam as regras. Silêncios foram apenas identificados diante de imagens mais distantes da decência e da modéstia recomendadas. Logo, ao mesmo tempo que as mulheres dialogam com normas religiosas, flertam com o look da moda, levando a uma travessia do sagrado para o secular. Por seu turno, as postagens indicam normas religiosas sendo ressignificadas a partir da apresentação de novas possibilidades estéticas.

Quando analisamos as imagens, surpreendemo-nos com muitas estéticas livres das normas religiosas. Novas mídias, como o Instagram, diluem a rígida comunidade religiosa, permitindo a essas mulheres, influenciadoras digitais, serem empreendedoras de si mesmas (HAN, 2017). 0 ambiente de numerosas estéticas postadas de forma rápida parece não dar espaço para críticas ou qualquer tipo de observação relativa ao não cumprimento das regras, o que Han denomina de "sociedade da exposição" $(2017,18)$, na qual a positividade pode não deixar espaço para a negatividade. 
Han ajuda-nos ainda a compreender que na sociedade da transparência as comunidades digitais têm outro sentido, pois podem ser caracterizadas como ajuntamentos e agrupamentos de diversos indivíduos isolados singularmente, que se reúnem em torno de religião, assim como também acontece com comunidades ligadas a uma marca, que não possuem uma coesão interna, embora sejam um grupo ativo $(2017,61)$.

Entendemos que as negociações estão associadas a estruturas e a relações de poder. Cova e Cova (2009) sugerem, por exemplo, que o poder não mais envolve conquistar ou possuir coisas, mas produzir e provocar um grupo de forma que ele possa desenvolver competências, assim como as assembleianas que tiveram suas postagens analisadas. Assim, as três resoluções que estabeleceram as normas formais para o consumo de moda e beleza pelas assembleianas no século XX foram produzidas por uma instituição religiosa dirigida por homens. Porém, no século XXI, essas consumidoras convergem para as redes sociais, nas quais provocam, desenvolvem competência influenciadora e negociam regras religiosas usando desse capital cultural (Bourdieu, 1986), principalmente a partir dos looks postados, indicando mudanças culturais mediadas por avanços tecnológicos na sociedade da transparência de Han (2017).

0 presente estudo permitiu decodificar, portanto, a partir de performances individuais, movimentos de significados (MCCRACKEN, 2003) das normas religiosas negociadas nas postagens do Instagram. Tal decodificação aponta para os modos como o capital cultural da moda promove as negociações simbólicas no ambiente da rede social, mediada pelas interações que a relação entre o que é exposto $X$ reações recebidas possibilita o borramento das fronteiras das normas ao receber a aprovação social. 


\section{Referências}

ALBUQUERQUE, Hortência Cruz de; DUQUE-ARRAZOLA, Laura Susana; ROCHA, Maria Alice Vasconcelos. Santas e estilosas: o consumo de moda gospel por mulheres pentecostais. Oikos: Família e Sociedade em Debate, v. 28, n. 2, 2018, p.316-331. Disponível em: https:// periodicos.ufv.br/oikos/article/view/3757. Acesso em: 30 ago. 2018.

ALVES, Maria de Fátima Paz. Um/uma jovem separado/a no mundo: igreja, juventude e sexualidade na perspectiva de jovens da Assembleia de Deus em Recife PE. 2009. 317 f. Tese (Doutorado em Antropologia) - Programa de Pós-Graduação em Antropologia, Universidade Federal de Pernambuco, Recife, 2009. Disponível em: https://repositorio. ufpe.br/handle/123456789/509. Acesso em: 3 out. 2018.

ALVES, Maria de Fátima Paz. Religião e sexualidade: permanências e transformações da perspectiva de jovens pentecostais de Recife/PE - Brasil. Ciencias Sociales y Religión/ Ciências Sociais e Religião, v. 13, n. 15, 2012, p. 83-113. Disponível em: https://doi. org/10.22456/1982-2650.19975. Acesso em: 16 dez. 2019.

ALENCAR, Glauber. Aspectos da cultura pentecostal brasileira: origem, influências e desenvolvimento. 2015. 51 f. Dissertação (Mestrado em Ciências da Religião) - Programa de Pós-Graduação em Ciências da Religião, Universidade Presbiteriana Mackenzie, São Paulo, 2015. Disponível de: http://tede.mackenzie.br/jspui/handle/tede/2820. Acesso em: 28 set. 2018.

BELK, Russell; GER, Güliz.; ASKEGAARD, Soren. The fire of desire: a multisited inquiry into consumer passion. Journal of Consumer Research, v. 30, n. 3, 2005, p. 326-351. Disponível em: https://doi.org/10.2139/ssrn.354640. Acesso em: 16 dez. 2019.

BELK, Russell; WALLENDORF, M.; \& SHERRY, J. F. The sacred and the profane in consumer behavior: theodicy on the odyssey. Journal of Consumer Research, v. 16, n. 1, 1989, p. 1-38. https://doi.org/10.1086/209191. Acesso em: 13 abr. 2020.

BOURDIEU, Pierre. The forms of capital. In: RICHARDSON, John (ed.) Handbook of theory and research for the Sociology of Education. New York: Greenwood, 1986. p. 241-58.

BOURDIEU, Pierre. Genesis and structure of the religious field. Comparative Social Research, v. 13, n. 1, 1991, p. 1-44,. Disponível em: https://docs.google.com/file/ d/0BxEZ9xOtQkn2X1RWZHVTZTdyMUk/edit. Acesso em: 30 abr. 2020.

CALIANDRO, Alessandro. Digital methods for ethnography: analytical concepts for ethnographers exploring social media environments. Journal of Contemporary Ethnography, v. 47, n. 5, 2018, p. 551-578. Disponível em: https://doi.org/10.1177/0891241617702960. Acesso em: 23 jun. 2020. 
CAMPOS, Leonildo Silveira. As origens norte-americanas do pentecostalismo brasileiro. Revista USP, n. 67, 2005, p. 100-115. Disponível em: https://www.revistas.usp.br/revusp/ article/download/13458/15276. Acesso em: 04 out. 2018.

CEZAR, Marina Seibert. A estética como comprovação da devoção. Revista dObra[s] (on-line), v. 4, n. 10, 2010, p. 97-105. Disponível em: https://doi.org/10.26563/dobras. v4i10.190. Acesso em: 14 jul. 2020.

COVA, Bernard; COVA, Véronique. Faces of the new consumer: a genesis of consumer governmentality. Recherche et applications en marketing (english edition), v. 24, n. 3, 2009, p. 81-89. Disponível em: https://doi.org/10.1177\%2F205157070902400304. Acesso em: 03 ago. 2020.

FERREIRA, Ismael de Vasconcelos. Ascetismo e sectarismo no pentecostalismo clássico das Assembleias de Deus. Protestantismo em Revista, São Leopoldo, v. 39, 2015, p. 21-35. Disponível em: http://dx.doi.org/10.22351/nepp.v39i0.2455. Acesso em: 16 dez. 2019.

FONSECA, André Dioney. Os impressos institucionais como fonte de estudo do pentecostalismo: uma análise a partir do livro história da convenção geral das Assembleias de Deus no Brasil. Revista Eletrônica História em Reflexão, Dourados, v. 3, n. 5, 2009a, p. 1-21. Disponível em: http://ojs.ufgd.edu.br/index.php/historiaemreflexao/article/ view/206/183. Acesso em: 27 ago. 2018.

FONSECA, André Dioney. São Cristóvão e Santo André: os debates sobre a normatização dos usos e costumes nas convenções gerais das Assembleias de Deus no Brasil (1930-1980). Sacrilegens, Juiz de Fora, v. 6, n. 1, 2009b, p. 41-59. Disponível em: http://www.ufff.br/ sacrilegens/files/2010/04/6-5.pdf. Acesso em: 23 mar. 2020.

FRESTON, Paul. Pentecostalism in Brazil: a brief history. Religion, v. 25, n. 2, 1995, p. 119 133. Disponível em: https://doi.org/10.1006/reli.1995.0012. Acesso em: 02 abr. 2020.

GARCIA, Carol; MIRANDA, Ana Paula Celso de. Moda é comunicação: experiências, memórias, vínculos. Coleção Moda \& Comunicação. Coord. Kathia Castilho. São Paulo: Ed. Anhembi Morumbi, 2005.

HAN, Byung-Chul. Sociedade da transparência. Trad. Eni Paulo Gianchini. Petrópolis: Vozes, 2017.

IBGE. Censo Demográfico 2010 - características gerais da população - resultados da amostra. Tabela 1.4.1 - População residente, por situação do domicílio e sexo, segundo os grupos de religião - Brasil - 2010. Disponível em: https://www.ibge.gov.br/estatisticas/ sociais/populacao/9662-censo-demografico-2010.html?=\&t=downloads. Acesso em: 8 abr. 2020. 
JACOBS, Arnold J. The year of living biblically. New York: Simon \& Schuster, 2007.

MCALEXANDER, James. H.; DUFAULT, Beth Leavenworth; MARTIN, Diane. M.; SCHOUTEN, John. W. The marketization of religion: field, capital, and consumer identity. Journal of Consumer Research, v. 41, n. 3, 2014, p. 858-875. Disponível em: https://doi. org/10.1086/677894. Acesso em: 4 jan. 2020.

MCCRACKEN, Grant. Cultura e consumo: novas abordagens ao caráter simbólico dos bens e das atividades de consumo. Coleção Cultura e Consumo. Tradução Fernanda Eugênio. Revisão Everardo Rocha. Rio de Janeiro: MAUD, 2003.

MACIEL, Eduardo Jorge Carvalho; MIRANDA, Ana Paula Celso de. DNA da imagem de moda. In: Colóquio Nacional de Moda, 5, 2009. Recife. Anais [...]. São Paulo: Abepem, 2009. Disponível em: http://www.coloquiomoda.com.br/anais/Coloquio\%20de\%20Moda\%20 -\%202009/ Consumo-de-Moda/. Acesso em: 1o jun. 2020.

MIRANDA, Ana Paula Celso de; ROCHA, Ana Rachel Consumption and constraint: muslim women fashion and identity. In: Congresso Internacional de Moda e Design - CIMODE, 2016, Buenos Aires. Anais do Congresso Internacional de Moda e Design - CIMODE, 2016.

MULINA, Franciani Fernandes Galvão. Liminaridade e cultura de consumo: objeto e expressão de consumo do neófito da religião protestante. 2019. 239 f. Tese (Doutorado em Administração) - Programa de Pós-graduação em Administração, Faculdade de Administração, Universidade Estadual de Maringá, Maringá, 2019.

O'GUINN, Thomas; BELK, Russell. Heaven on Earth: consumption at heritage village, USA. Journal of Consumer Research, v. 16, n. 2, 1989, p. 227-238. Disponível em: https://doi. org/10.1086/209211. Acesso em: 18 ago. 2020.

PENN, Gemma. Análise semiótica de imagens paradas. In: BAUER, Martin.; GASKELL, George. Pesquisa qualitativa com texto, imagem e som: um manual prático. 5. ed. Petrópolis: Vozes, 2002. p. 319-342.

PORTELLA, Rodrigo. Pentecostalismo clássico e valores de autonomia: sobre o poder simbólico das representações pentecostais. Revista de Teologia (Reveleteo), v. 6, n. 10, 2012, p. 3-15. Disponível em: https://doi.org/10.23925/2177-952X.2012v6i10pp.\%200315. Acesso em: 16 dez. 2019.

RAUF, Ateeq Abdul; PRASAD, Ajnesh.; \& AHMED, Abdullah. How does religion discipline the consumer subject? Negotiating the paradoxical tension between consumer desire and the social order. Journal of Marketing Management, v. 35, n. 5-6, 2019, p. 491-513. Disponível em: https://doi.org/10.1080/0267257X.2018.1554599. Acesso em: 13 dez. 2019. 
RENTAS VEGA, Ananís. (Un)spoken codes: Is the new generation breaking the Pentecostal dress code?. Major papers by master of science students. Paper 7. 2019. Disponível em: https://digitalcommons.uri.edu/tmd_major_papers/7https://digitalcommons.uri.edu/ tmd_major_papers/7. Acesso em: 5 mar. 2020.

SANDIKCI, Özlem; GER, Güliz. Veiling in style: how does a stigmatized practice become fashionable?. Journal of Consumer Research, v. 37, n. 1, 2010, p. 15-36.

Disponível em: https://doi.org/10.1086/649910. Acesso em: 4 jan. 2020.

SOBH, Rana; BELK, Russel; GRESSEL, Justin. Modest seductiveness: reconciling modesty and vanity by reverse assimilation and double resistance. Journal of Consumer Behavior, v. 11, n. 5, 2012, p. 357-367. Disponível em: https://doi.org/10.1002/cb.1379. Acesso em: 4 jan. 2020.

SOBH, Rana; BELK, Russel; GRESSEL, Justin. Mimicry and modernity in the Middle East: fashion invisibility and young women of the Arab Gulf. Consumption Markets and Culture, v. 17, n. 4, 2014, p. 392-412. Disponível em: https://doi.org/10.1080/10253866.2013.8651 66. Acesso em: 4 jan. 2020.

TERRACIANO, B. 0 discurso da moda nas redes sociais. Revista dObra[s] (on-line), v. 6, n. 14, 2013, p. 117-127. Disponível em: https://doi.org/10.26563/dobras.v6i14.80. Acesso em: 14 jun. 2020.

VERTER, Bianca. Spiritual capital: theorizing religion with Bourdieu against Bourdieu. Sociological Theory, v. 21, n. 2, 2003, p. 150-74. Disponível em: https://doi. org/10.1111/1467-9558.00182. Acesso em: 14 jun. 2020.

\section{Agradecimentos}

Pesquisa realizada com financiamento por meio de Bolsa de Mestrado da Fundação CAPES - Coordenação de Aperfeiçoamento de Pessoal de Nível Superior.

Agradecemos ao revisor Alexandre Florêncio do Santos, que gentilmente colaborou na redação final deste artigo. 